\title{
Prevention of toxic effects of cyclosporin on pancreatic B-cells of rats by Rioprostil, a new prostaglandin analogue
}

\author{
M K MÜLLER, H DEGENHARDT, G KLÖPPEL, H GOEBELL, \\ K BERGMANN, AND M LÖHR \\ From the Division of Gastroenterology, Department of Medicine, University of Essen and Department of \\ Pathology, University of Hamburg, FRG
}

SUMmary Cyclosporin 5,10 , and $20 \mathrm{mg} / \mathrm{kg}$ bw was given to rats once daily intragastrically and caused a dose dependent, significant decrease of glucose dependent insulin release from the arterially perfused isolated pancreas, without affecting animal behaviour, weight gain, microscopic appearances of the pancreas, or kidney function. Subcutaneous injection of a new synthetic prostaglandin analogue Rioprostil $7.5 \mu \mathrm{g} / \mathrm{kg}$ bw twice daily completely prevented the effect of cyclosporin $5 \mathrm{mg} / \mathrm{kg}$ bw and protected significantly against the effects of cyclosporin 10 and $20 \mathrm{mg} /$ kg bw.

Cyclosporin is a cyclic peptide of 11 aminoacids. First isolated as an antifungal agent, this substance has proved to be a powerful immunosuppressive agent in the prevention of graft rejection after the transplantation of solid organs or bone marrow and in the control of autoimmune diseases. ${ }^{1}$ Its action is different from that of other immunosuppressive drugs in that it is not an alkylating or antimitotic agent, but rather selectively affects T-lymphocytes and inhibits the production and secretion of the helper cell-factor interleukin 2 and other lymphokinins. ${ }^{2}$ Its adverse effects are also different from those of other immunosuppressive drugs including dose related nephrotoxicity and hepatoxicity. ${ }^{34}$

It has been shown recently in rats that chronic administration of cyclosporin causes severe degranulation and hydropic degeneration of islet B-cells ${ }^{5}$ and a decrease in insulin content and secretion. ${ }^{67}$

Prostaglandins have attracted great interest because of their ability to prevent damage to the stomach from contact necrosis induced by a variety of noxious agents, ${ }^{8}$ to prevent liver necrosis caused by agents such as carbon tetrachloride, ${ }^{9}$ galacto-

Address for correspondence: M K Müller, MD, Division of Gastroenterology, Department of Medicine, University of Essen, Hufelandstr 55, 4300 Essen, 1 FRG.

Received for publication 1 June 1988. samine,$^{10}$ and ethanol ${ }^{11}$ and to decrease the severity of diet induced acute pancreatitis in mice. ${ }^{12}$ This study was undertaken to test the possibility that the new synthetic prostaglandin Rioprostil, a primary alcohol analogue of prostaglandin $\mathrm{PGE}_{1}$ (2-decarboxy-2hydroxymethy-15-deoxy-16RS-hydroxy-16-methyl $\mathrm{PGE}_{1}$ ) which has gastric antisecretory and cytoprotective properties, ${ }^{13}$ would be able to protect the pancreas against cyclosporin induced damage.

\section{Methods}

RATS

Male Wistar strain rats (220-240 g) were used throughout the study. Rioprostil was a generous gift from Bayer (Wuppertal, FRG). It is a newly developed prostaglandin $E_{1}$ analogue which is stable in alcohol with a molecular weight of 354.5 . It was injected subcutaneously twice daily. Cyclosporin (Sandimmun) was purchased from Sandoz (Basel, Switzerland) and was dissolved in olive oil and was applied intragastrically by a metal feeding tube once daily in the morning.

DESIGN OF THE STUDY

Eight groups of rats were tested. Each group consisted of eight to 10 animals. The animals were 


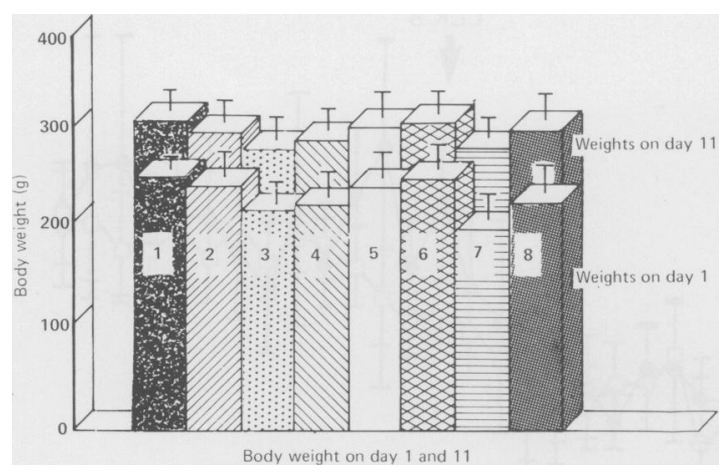

Fig. 1 Comparison of the weight gains of control animals (group 1 olive oil, group 5 Rioprostil $2 \times 7.5 \mu \mathrm{g} / \mathrm{kg}$ ) with groups treated with cyclosporin (group 2 cyclosporin $5 \mathrm{mg}$ / $\mathrm{kg}$, group 3 cyclosporin $10 \mathrm{mg} / \mathrm{kg}$, group 4 cyclosporin 20 $\mathrm{mg} / \mathrm{kg}$ ) and those treated with the combination Rioprostil and cyclosporin (group 6 Rioprostil and cyclosporin $5 \mathrm{mg} / \mathrm{kg}$, group 7 Rioprostil and cyclosporin $10 \mathrm{mg} / \mathrm{kg}$, group 8 Rioprostil and $20 \mathrm{mg} / \mathrm{kg}$ ). There were no significant differences between all groups in the gain in weight.

treated according to their body weights as follows: group 1 olive oil, group 2 cyclosporin $5 \mathrm{mg} / \mathrm{kg}$, group 3 cyclosporin $10 \mathrm{mg} / \mathrm{kg}$, group 4 cyclosporin $20 \mathrm{mg} /$ $\mathrm{kg}$, group 5 Rioprostil $2 \times 7.5 \mu \mathrm{g} / \mathrm{kg}$, group 6 cyclosporin $5 \mathrm{mg} / \mathrm{kg}$ and Rioprostil $2 \times 7.5 \mu \mathrm{g} / \mathrm{kg}$, group 7 cyclosporin $10 \mathrm{mg} / \mathrm{kg}$ and Rioprostil $2 \times 7.5 \mu \mathrm{g} / \mathrm{kg}$, group 8 cyclosporin $20 \mathrm{mg} / \mathrm{kg}$ and Rioprostil $2 \times 7 \cdot 5$ $\mu \mathrm{g} / \mathrm{kg}$.

Rioprostil was injected from day 1 to day 11 . Cyclosporin treatment began at day 4 and was continued to day 11. All groups had free access to food and water. Before operation on day 12 they fasted for 16-18 hours with free access to water.

ISOLATED PERFUSED PANCREAS PREPARATION The pancreas was isolated and perfused as described previously. ${ }^{14}$ The preparation consisted of pancreas with a small remnant of duodenum. The preparation was perfused through the superior mesenteric artery and the coeliac trunc at a constant flow rate of $4 \mathrm{ml} / \mathrm{min}$ without recirculation. The perfusate was collected in one minute intervals by inserting a second cannula (PE 160) into the portal vein.

The perfusate consisted of Krebs-Ringer bicarbonate buffer containing $0 \cdot 2 \%$ bovine serum albumin, $3 \%$ dextran, 7.9 or $15.8 \mathrm{mM}$ glucose. The perfusate was gassed with $95 \% \mathrm{O}_{2}-5 \% \mathrm{CO}_{2}$ to achieve a final $\mathrm{pH}$ of $7 \cdot 4$.

\section{LIGHT MICROSCOPY}

Serial sections of paraffin embedded, Bouin fixed pancreases, $3 \mu \mathrm{m}$ thick, were cut. The first two sections were stained with $\mathrm{H}$ and $\mathrm{E}$ and periodic acid
Schiff (PAS). Immunocytochemistry was carried out on the subsequent deparaffinised serial sections, using the peroxidase technique with the avidin biotincomplex (ABC) and antibodies against insulin (monoclonal), glucagon, somatostatin, and pancreatic polypeptide (PP).

\section{EXPERIMENTAL DESIGN}

The preparation was equilibrated by perfusion for 15 minutes with a buffer containing $7.9 \mathrm{mM}$ glucose. After equilibration the buffer was switched to a glucose concentration of $.15 .8 \mathrm{mM}$ glucose. To potentiate glucose dependent insulin secretion, CCK 8 was concomitantly injected after 15 minutes through a side arm to result in a final concentration of $100 \mathrm{pg} / \mathrm{ml}$.

\section{ANALYSIS}

Insulin was determined radioimmunologically in the perfusate as described previously. ${ }^{14}$ Cyclosporin was determined in blood before operation using radioimmunoassay kits (Sandoz, Basel). Creatinine was determined in serum before operation using a Beckman analyser. The animals were weighed daily.

\section{STATISTICAL ANALYSIS}

Insulin secretion from the endocrine pancreas is presented as output per minute. Total outputs during stimulation with $15.8 \mathrm{mM}$ glucose and CCK 8 and cyclosporin blood concentrations were compared with Student's $t$ test for unpaired data, and differences with $p$ values $<0.05$ were considered statistically significant. Animal weights were compared with a two-way analysis of variance. Data are expressed as mean (SE).

\section{Results}

EFFECTS OF CYCLOSPORIN AND RIOPROSTIL ON ANIMAL BEHAVIOUR, SERUM CREATININE CONCENTRATIONS, AND MICROSCOPIC APPEARANCE OF THE PANCREASES

None of the rats showed any adverse reactions or unusual behaviour throughout the study. The serum

Table 1 Blood concentrations of cyclosporin $(\mathrm{ng} / \mathrm{ml})$ in groups with or without treatment with Rioprostil

\begin{tabular}{lcc}
\hline & \multicolumn{2}{l}{ Rioprostil } \\
\cline { 2 - 3 } & - & + \\
\hline Cyclosporin $5 \mathrm{mg} / \mathrm{kg}$ & $146(24)$ & $139(14) \mathrm{NS}$ \\
Cyclosporin $10 \mathrm{mg} / \mathrm{kg}$ & $962(122)$ & $781(173) \mathrm{NS}$ \\
Cyclosporin $20 \mathrm{mg} / \mathrm{kg}$ & $2112(85)$ & $2127(73) \mathrm{NS}$ \\
\hline
\end{tabular}

$\mathrm{n}=10$. 


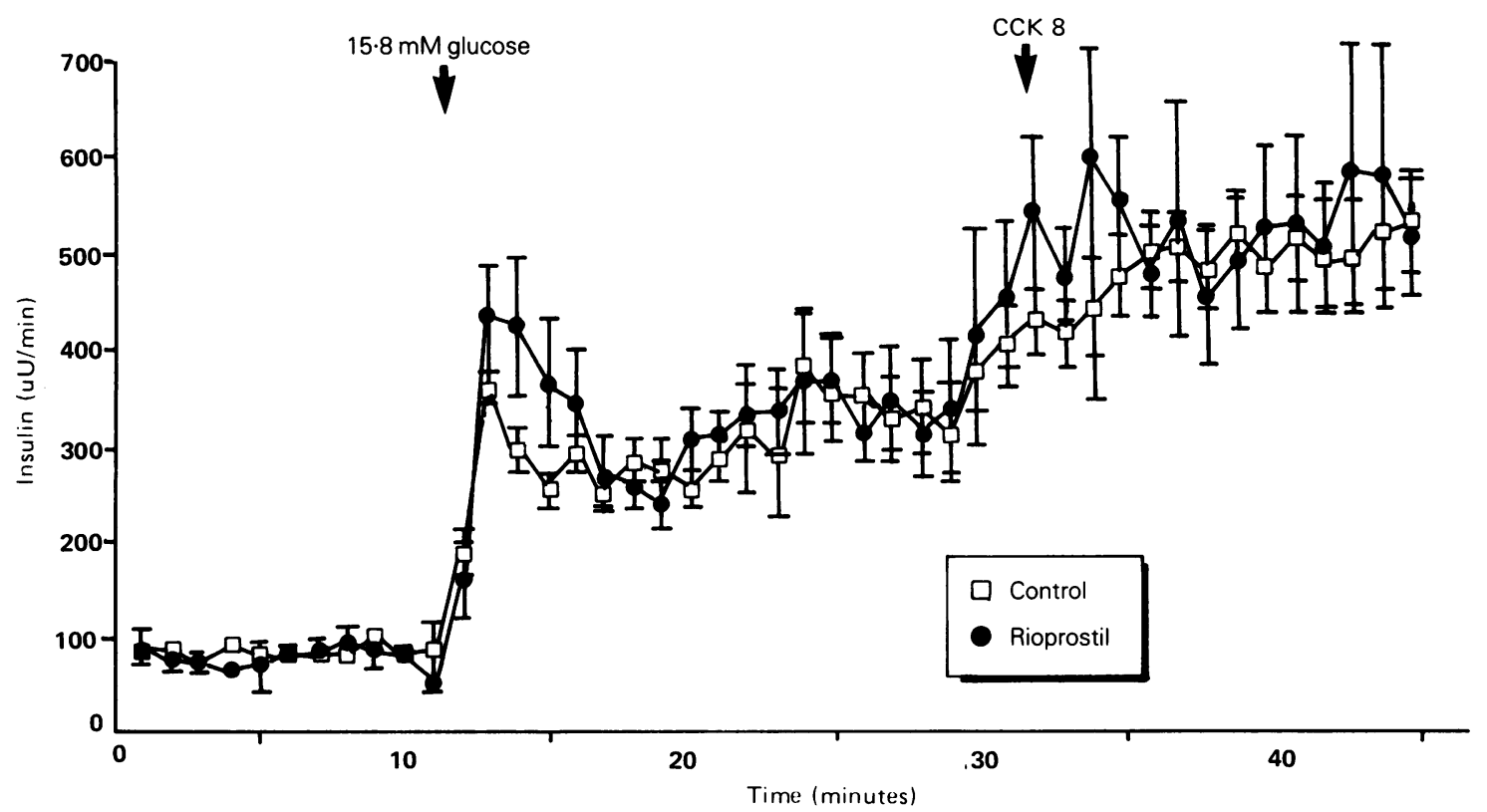

Fig. 2 Effect of Rioprostil on glucose dependent insulin secretion. Rioprostil did not significantly influence insulin secretion. $\square$-control, $\mathbf{\square}-$ Rioprostil $(n=8)$.

creatinine concentrations of all animals were in the normal range with a mean level of $0.5(0 \cdot 01) \mathrm{mg} / \mathrm{dl}$. Light microscopy and immunocytochemistry revealed no differences in the appearance of control pancreases, pancreases treated with cyclosporin, Rioprostil, or combination Rioprostil and cyclosporin. In particular no degranulation or hydropic degeneration could be detected in the cyclosporintreated animals.

EFFECTS OF CYCLOSPORIN AND RIOPROSTIL ON . ANIMAL WEIGHT GAIN

Animal weight gain was neither influenced by cyclosporin nor by Rioprostil. Each group of animals

Table 2 Total insulin output $(m U)$ during stimulation with $15.8 \mathrm{mM}$ glucose and CCK 8 in groups with (+) or without (-) treatment with Rioprostil

\begin{tabular}{lrr}
\hline Total insulin output in $\mathrm{mU}$ & \multicolumn{2}{l}{ Rioprostil } \\
\cline { 2 - 3 } & - & + \\
\hline Control, oil & $13.7(1.4)$ & $15 \cdot 2(1 \cdot 8) \mathrm{NS}$ \\
Cyclosporin $5 \mathrm{mg} / \mathrm{kg}$ & $7 \cdot 8(1.0)$ & $13.4(1 \cdot 3) \mathrm{p}<0.005$ \\
Cyclosporin $10 \mathrm{mg} / \mathrm{kg}$ & $7 \cdot 4(0 \cdot 6)$ & $11 \cdot 0(1 \cdot 6) \mathrm{p}<0.050$ \\
Cyclosporin $20 \mathrm{mg} / \mathrm{kg}$ & $5 \cdot 7(1 \cdot 1)$ & $9 \cdot 1(1.5) \mathrm{p}<0.050$ \\
\hline
\end{tabular}

$\mathrm{n}=8$. experienced a similar increase in weight during the test period (Fig. 1).

\section{RELATIONSHIP BETWEEN INTRAGASTRAL}

APPLIED CYCLOSPORIN AND BLOOD

CONCENTRATIONS OF CYCLOSPORIN IN GROUPS WITH OR WITHOUT SUBCUTANEOUS TREATMENT WITH RIOPROSTIL

Blood levels were taken 18-20 hours after the last application of cyclosporin. Subcutaneous application of Rioprostil did not significantly influence the blood levels of cyclosporin (Table 1).

EFFECTS OF CYCLOSPORIN AND RIOPROSTIL ON GLUCOSE-DEPENDENT INSULIN SECRETION

Five milligrams per kilogram of cyclosporin applied intragastrically caused an almost $50 \%$ reduction in insulin release (Fig. 2, Table 2). The effect of $10 \mathrm{mg} /$ kg was not significantly different (Fig. 3, Table 2). A significant further reduction was found with the dosage of $20 \mathrm{mg} / \mathrm{kg}$ cyclosporin (Fig. 4, Table 2). Subcutaneous injection of Rioprostil at a dosage of $7.5 \mu \mathrm{g} / \mathrm{kg}$ twice daily did not influence insulin secretion in controls (Fig. 5, Table 2). This dose of Rioprostil could almost completely protect the Bcells from the noxious effect of $5 \mathrm{mg} / \mathrm{kg}$ cyclosporin (Fig. 2, Table 2). This cytoprotective effect was less, but still significantly pronounced at $10 \mathrm{mg} / \mathrm{kg}$ cyclosporin and $20 \mathrm{mg} / \mathrm{kg}$ (Figs 3 and 4, Table 2). 


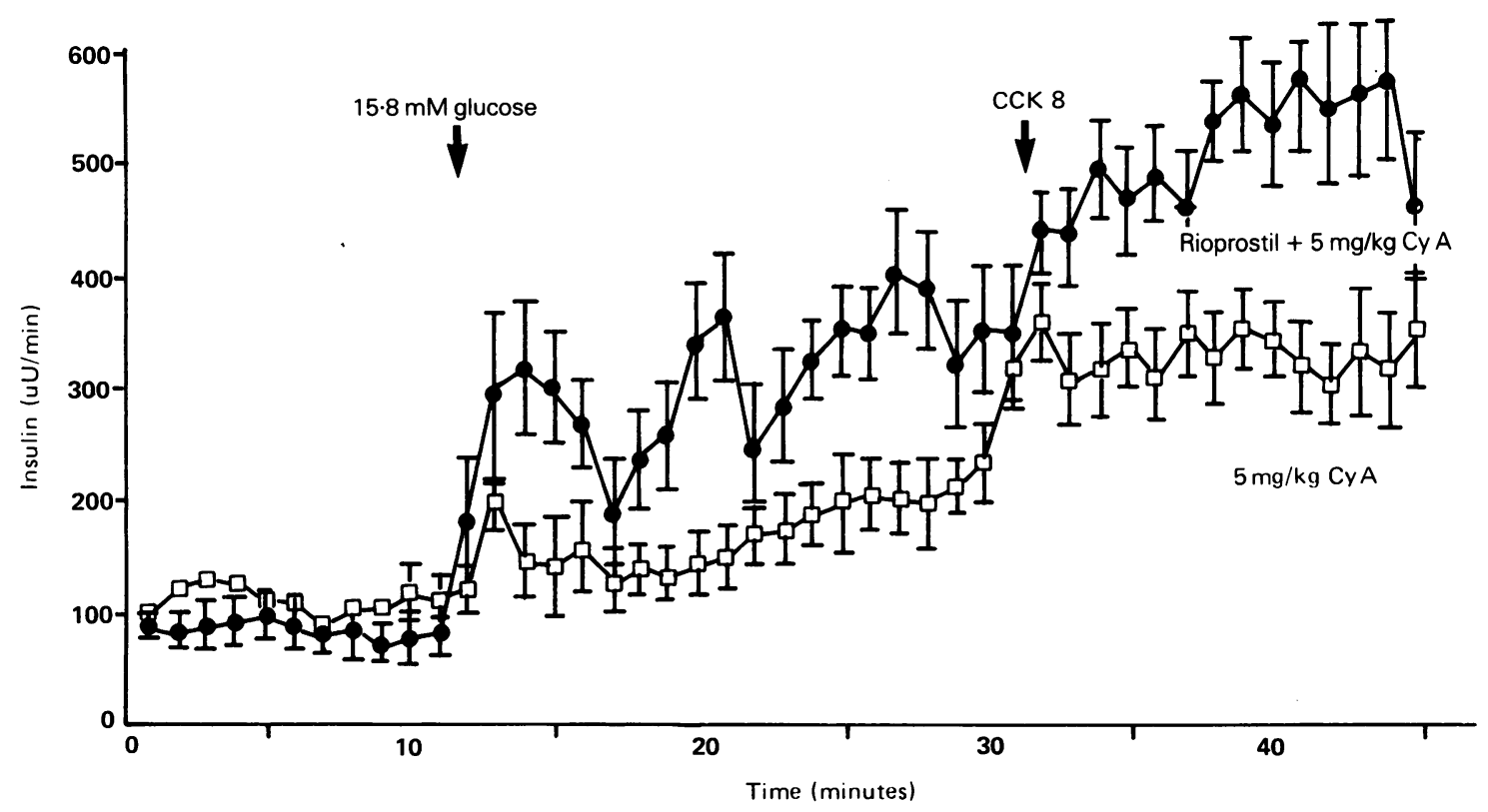

Fig. 3 Effect of Rioprostil on insulin secretion of the pancreata of animals treated with $5 \mathrm{mg} / \mathrm{kg}$ cyclosporin. Rioprostil can almost completely prevent a reduction in insulin secretion caused by cyclosporin (total insulin secretion after stimulation with $15.8 \mathrm{mM}$ glucose $7 \cdot 8(1.0)$ v $13.4(1.3) \mathrm{mU})(n=8)$.

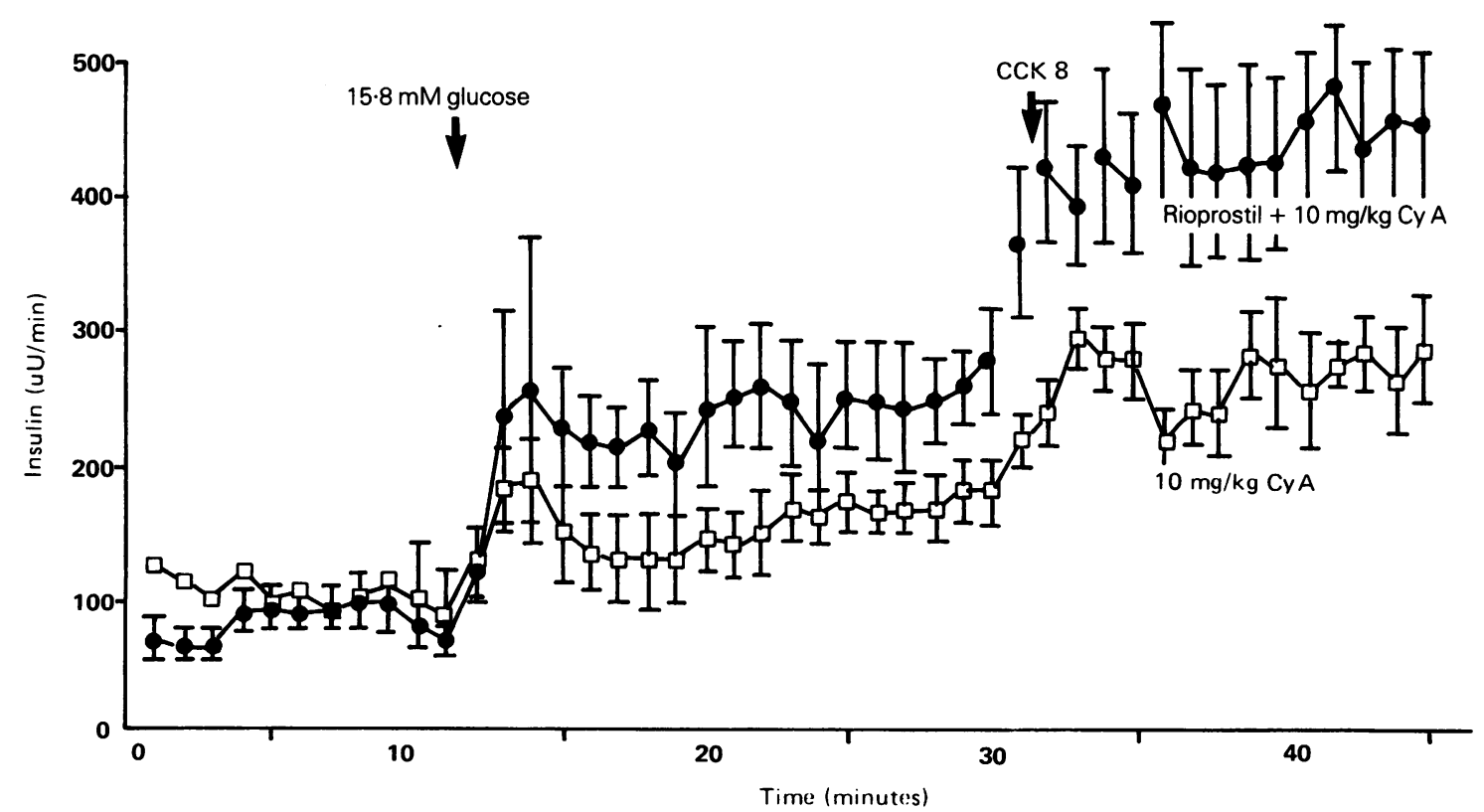

Fig. 4 Effect of Rioprostil on insulin secretion of the pancreata of animals treated with $10 \mathrm{mg} / \mathrm{kg}$ cyclosporin. Rioprostil can significantly protect the B-cells from the noxious effect of cyclosporin although the effect is less pronounced than at $5 \mathrm{mg} / \mathrm{kg}$ cyclosporin (total insulin secretion after stimulation with $15 \cdot 8 \mathrm{mM}$ glucose $7.4(0 \cdot 6)$ v $11 \cdot 0(1 \cdot 6) \mathrm{mU})(n=8)$. 


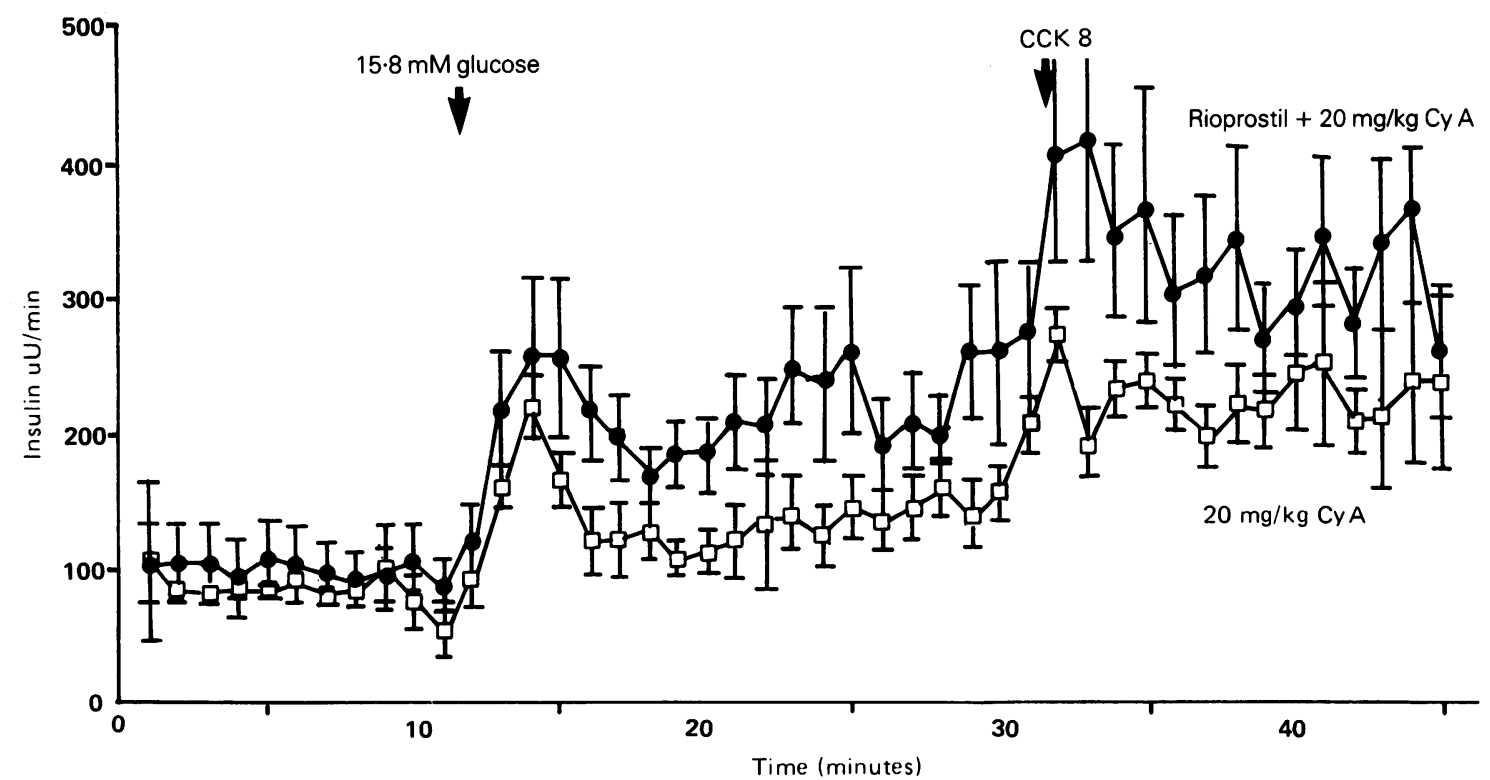

Fig. 5 Effect of Rioprostil on insulin secretion of the pancreata of animals treated with $20 \mathrm{mg} / \mathrm{kg}$ cyclosporin. The cytoprotective effect of Rioprostil is still visible and significant when calculating total insulin secretion after stimulation with $15.8 \mathrm{mM}$ glucose $(5 \cdot 7(1 \cdot 1)$ v $9 \cdot 1(1 \cdot 5) \mathrm{mU})(n=8)$.

EFFECT OF RIOPROSTIL ON CYCLOSPORIN

ABSORPTION FROM THE GUT

To exclude the possibility that Rioprostil would affect peak levels of cyclosporin in the blood by interfering with absorption from the gut, cyclosporin was applied intragastrically in a bolus of $5 \mathrm{mg} /$ $\mathrm{kg}$ in the presence or absence of $15 \mu \mathrm{g} / \mathrm{kg}$ Rioprostil. We found that Rioprostil has no significant effect on the blood concentrations of cyclosporin (Fig. 6).

\section{Discussion}

The present study confirms previous findings that cyclosporin causes severe impairment of glucose dependent insulin secretion. . $^{5-7}$ In contrast with previous studies the doses which were used neither affected animal weight gain, nor produced light microscopic changes in the pancreas, nor were they nephrotoxic. Glucose dependent insulin secretion and its potentiation by $\mathrm{CCK} 8$, however, were already markedly reduced. At the lowest dose of cyclosporin (5 $\mathrm{mg} / \mathrm{kg})$, insulin secretion was impaired by almost $50 \%$ after eight days of treatment. This noxious effect of cyclosporin could be completely prevented by the parenteral administration of Rioprostil, a PGE 1 analogue in a dosage of 7.5 $\mu \mathrm{g} / \mathrm{kg}$ twice daily. The impairment of insulin secretion with doses which were not nephrotoxic suggests that the pancreatic B-cells of rat are more sensitive to cyclosporin toxicity than kidney cells.

The ability to show the beneficial effects of prostaglandins depends on several factors. One is that treatment of the prostaglandins before the introduction of noxious agents is essential in order to gain the most beneficial effects. ${ }^{15}$ This was the reason for starting with the parenteral administration of Rioprostil before the intragastral application of cyclosporin. It has previously been shown in the rat stomach that the antiulcer and cytoprotective activity of Rioprostil sets in rapidly, and it is seen after only four minutes' pretreatment. ${ }^{16}$ Whether it is necessary or better to administer the prostaglandin analogue twice daily and to start pretreatment four days before applying cyclosporin will be the subject of further study.

Another factor which determines cytoprotective ability is its dependency on the dosage of noxious agents. ${ }^{15}$ This is clearly shown in the present study, where the greatest beneficial effect of Rioprostil is seen with the lowest dose of cyclosporin, resulting almost in complete protection. The cytoprotective effect is less, but still significantly pronounced at higher doses. Although no microscopic changes could be observed in the pancreas, even with the highest dose of cyclosporin, this finding probably reflects the extent of the functional derangement of insulin secretion.

Reports which have suggested that prostaglandins 


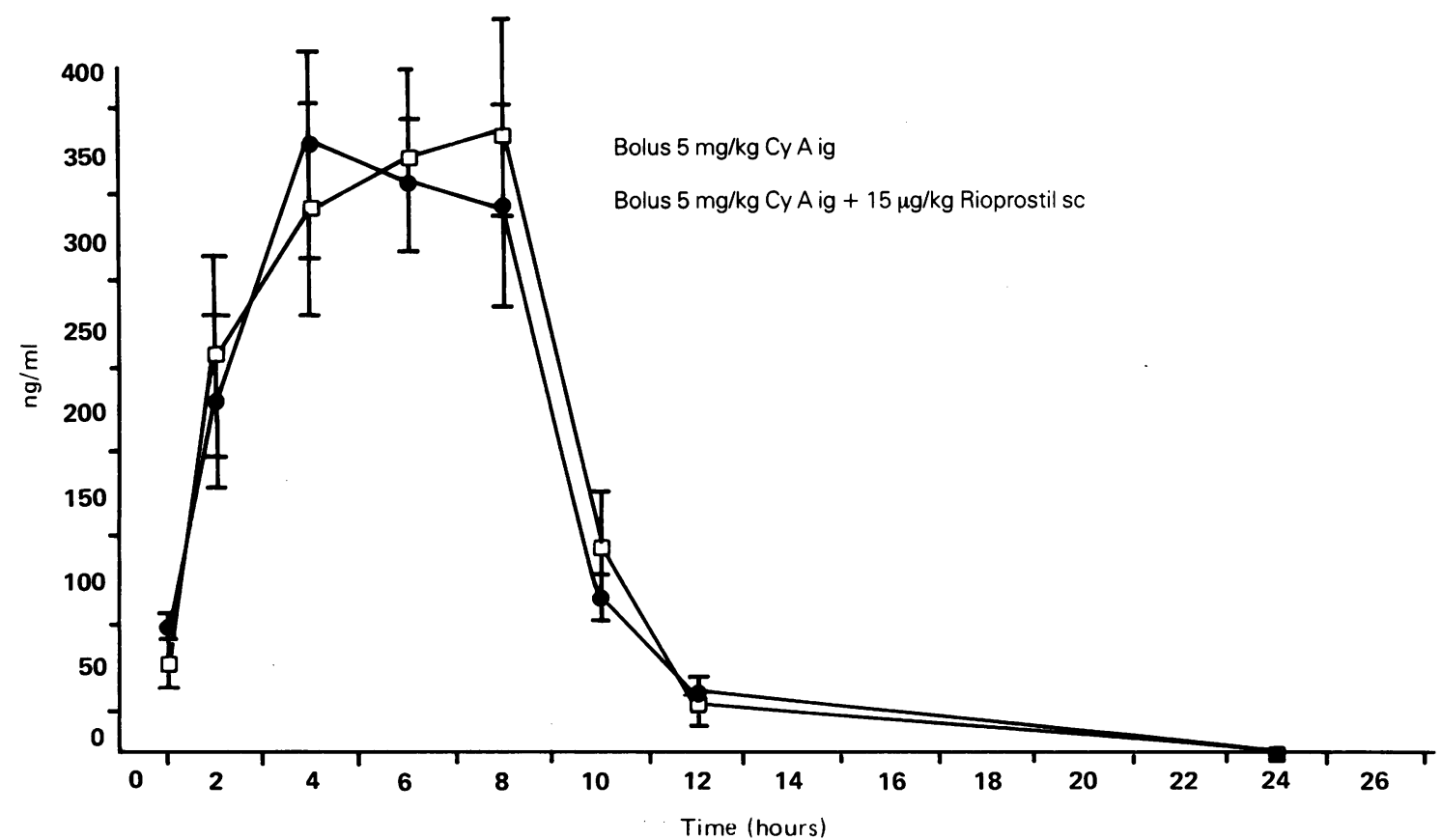

Fig. 6 Effect of Rioprostil on cyclosporin absorption from the gut. Rioprostil has no significant effect on cyclosporin absorption from the gut $(n=8)$.

can prevent diet induced pancreatitis and liver necrosis caused by various agents extend the concept of prostaglandin mediated cytoprotection to nonmucous secreting organs. The mechanism which is responsible for this cytoprotective action still has to be determined. There has been speculation that prostaglandins may act by stabilising cell membranes, ${ }^{8}$ that cytoprotection may be related to lysosomal stability, ${ }^{17}$ or that it may be related to stimulation of the RES by increasing macrophage migration into the pancreas and subsequent phagocytosis of cell debris. ${ }^{15}$ The evidence that Rioprostil markedly decreases damage to the pancreas against cyclosporin toxicity could have therapeutic implications for man. It remains to be determined, however, whether the immunosuppressive effect of cyclosporin will be influenced by Rioprostil.

We thank Lydia Blaudzum, Ruth Malik, Susanne Peters, Barbara Engel, and Heidi Karon for excellent technical assistance, Bayer for donating Rioprostil and for giving financial support.

\section{References}

1 Starzl TE. Clinical aspects of cyclosporine therapy: a summation. Transplant Proc [suppl] 1983; 15: 3103-7.

2 Stiller CR. The Canadian multicentre transplant study group: a randomized clinical trial of cyclosporine in cadaveric renal transplantation. N Engl J Med 1983; 309: 809-15.

3 Ota B, Bradley M. Side effects of cyclosporine in 100 renal allograft recipients. Transplant Proc [suppl] 1983; 15: 3150-6.

4 Myers B, Ross J, Newton L. Cyclosporine associated chronic nephropathy. $N$ Engl J Med 1984; 311: 699-705.

5 Helmchen U, Schmidt WE, Siegel EG, Creutzfeldt W. Morphological and functional changes of pancreatic B cells in cyclosporin A-treated rats. Diabetologia 1984; 27: 416-8.

6 Hahn HJ, Laube F, Lucke S, Klöting I, Kohnert KD, Warzock R. Toxic effects of cyclosporine on the endocrine pancreas of wistar rats. Transplantation 1986; 41 : 44-7.

7 Yale JF, Roy D, Grose M, Seemayer A, Murphy GF, Marliss EB. Effects of cyclosporine on glucose tolerance in the rat. Diabetes 1985; 34: 1309-13.

8 Robert A, Nezamis JE, Lancaster C, Hanchar AJ. Cytoprotection by prostaglandins in rats: prevention of gastric necrosis produced by alcohol, $\mathrm{HCl}, \mathrm{NaOH}$, hypertonic $\mathrm{NaCl}$, and thermal injury. Gastroenterology 1979; 77: 433-43.

9 Stachura J, Tarnaski A, Ivey KJ, et al. Prostaglandin protection of carbon tetrachloride-induced liver cell necrosis in the rat. Gastroenterology 1981; 81: 131-7.

10 Stachura J, Tarnawski A, Szcudrawa J, et al. Cytoprotective effect of 16,16-dimethy prostaglandine $E_{2}$ and some drugs on acute galactosamine induced liver damage in rat. Folia Histochem Cytochem 1980; 18: 311.

11 Stachura J, Tarnawski A, Ivey DJ, et al. 16,16-Dimethy 
prostaglandin $E_{2}$ protection of rat liver against acute injury by galactosamine, acetometaphin, ethanol and ANIT. Gastroenterology 1981; 80: 1349.

12 Coelle EF, Adham N, Elashoff J, Lewin K, Taylor IL. Effects of prostaglandin and indomethacin on dietinduced acute pancreatitis in mice. Gastroenterology 1981; 85: 1307-12.

13 Demol P, Wingender W, Weihrauch TR, Graefe KH. Inhibition of gastric secretion in man by rioprostil, a new synthetic methyl prostaglandin $\mathrm{E}_{1}$. Arzneim Forsch/ Drug Res 1985; 35: 861-3.

14 Müller MK, Demol P, Fladrich G, Goebell H, Pederson RA. Glucose-dependent insulinotropic action of chole- cystokinin octapeptide in the isolated perfused rat pancreas. Digestion 1983; 27: 245-51.

15 Taylor IL, Coelle EF, Adham NF. Factors that modify the effects of prostaglandin on diet induced acute pancreatitis in mice. Scand J Gastroenterol [suppl] 1985; 20: $101-5$.

16 Shriver DA, Rosenthale ME, Kluender HC, Schut RN, McGuire JL, Hong E. Pharmacology of rioprostil, a new gastric cytoprotective/antisecretory agent. Arzneim Forsch/Drug Res 1985; 35: 839-43.

17 Himal HS, Mowat C. Prostaglandin cytoprotection and lysosomal stability in acute canine gastric erosions. Can J Surgery 1983; 26: 142-3. 